\title{
Про деякі технічні й тактичні аспекти виконання ендовенозної лазерної коагулящії
}

\author{
V. B. HOSHCHYNSKYI, M. V. HAVRYLIUK, V. H. KOHUT \\ SHEI "Ternopil State Medical University by I. Ya. Horbachevsky"
}

\section{ABOUT SOME TECHNICAL AND TACTICAL ASPECTS OF THE ENDOVENOUS LAZER COAGULATION PERFORMANCE}

\begin{abstract}
У 253 хворих проаналізовано результати виконання ендовенозної лазерної коагуляції. Результати аналізу свідчать про те, що вирішення окремих технічних та тактичних питань, зокрема щільності лазерного випромінювання, необхідність виконання кросектомії, ультразвукове дослідження вен у різних положеннях паціснта для визначення показань до ендовенозної лазерної коагуляції дозволяють підвищити ефективність цього оперативного втручання.
\end{abstract}

The results of the endovenous laser coagulation was analyzed in 253 patients. The results of the analysis indicate that the solution of specific technical and tactical issues, such as the density of the laser radiation, the nesessity of crossectomy, ultrasound examination of veins in different positions of patients determine the indications for endovenous laser coagulation and can improve the effectiveness of this surgical intervention.

Постановка проблеми і аналіз останніх досліджень та публікацій. Застосування лазерних технологій, зокрема ендоваскулярної лазерної коагуляції вен (ЕВЛК), є пріоритетним напрямком у хірургічному лікуванні варикозної хвороби нижніх кінцівок (ВХНК). Це пояснюється малотравматичністю, косметичним ефектом та скороченням терміну відновлення працездатності. Тому ЕВЛК стала альтернативою класичній сафенектомії і деякою мірою ідеалізується як бездоганний метод лікування ВХНК. Однак, як показує аналіз літературних джерел, ЕВЛК має цілий ряд специфічних ускладнень, притаманних цій методиці (флебіти, гематоми за ходом коагульованої вени, екхімози або гіперпігментація шкіри, больовий синдром різної інтенсивності, реканалізація коагульованої вени), а також рецидив ВХНК $[3,4,6,8,9,10,11,12]$, які $€$ додатковими аргументами прихильників класичної “зондової” сафенектомії.

Якщо розглянути окремо вищеперераховані ускладнення, то їх можна умовно поділити на ускладнення технічного і тактичного плану. У зв'язку 3 цим, існують спірні питання щодо застосування для ЕВЛК “Н” (гемоглобінових) - лазерів із довжиною хвилі до 1000 нм та "W" (водних) - лазерів, довжина хвилі яких до 1500 нм [5]. Крім того, точаться дискусії щодо мінімальної щільності енергії лазерного випромінювання, достатньої для коагуляції вени [7, 15], доцільності виконання кросектомії під час виконання ЕВЛК [13, 14], навколо показань щодо застосування ЕВЛК при різних діаметрах великої або малої підшкірної вени [1] тощо. Безумовно, вирішення цих питань підвищить безпеку та ефективність ЕВЛК.

Мета роботи: провести аналіз методики виконання ЕВЛК із метою її удосконалення.

Матеріали і методи. Згідно з нашою класифікацією, хворі на ВХНК були поділені на три клінікосонографічні форми варикозного розширення - периферичну з ураженням колатеральних та із збереженим венозним тонусом магістралей підшкірних вен; магістральну - із локальним, сегментарним, поширеним, субтотальним та тотальним зниженням венозного тонусу головних венозних стовбурів; змішану, що поєднує ознаки попередніх двох [2]. Виходячи із цієї класифікації, для проведення ЕВЛК вибрано хворих із магістральною та змішаною формою ВХНК. Таким чином, у Тернопільському міському флебологічному центрі за період 20092012 рр. $з$ приводу варикозної хвороби було прооперовано 253 пацієнтів за методикою ЕВЛК (111 пацієнтів із магістральною та 142 - із змішаною формами ВХНК). Із них чоловіків - 104, жінок - 
149, віком від 26 до 54 років. Хворих на ВХНК за класифікацією СЕАР із С II було прооперовано 89 пацієнтів, із C III та C IV, відповідно, 113 та 51 хворий. При змішаній формі ВХНК ЕВЛК була доповнена у 108 (76,1 \%) випадках катетерним склерозуванням колатеральних вен та міні-флебектомією, a у 31 хворого $(21,8$ \%) ЕВЛК поєднувалася із ендоскопічною субфасціальною дисекцією вен. 54 пацієнтам ЕВЛК була проведена без кросектомії, при цьому торець світловода розташовувався на 1,0-1,5 см від сафено-феморального гирла. Позиція світловода контролювалась за допомогою лазерного червоного пілотного випромінювання (довжина хвилі 680 нм) та УЗД. Хворим перед оперативним втручанням проводили визначення функціонального стану глибокої та поверхневої венозної системи нижніх кінцівок за допомогою ультразвукового кольорового дуплексного сканування вен. Для цього був використаний апарат Vivid 3 (“Дженерал Електрик", США) з датчиком частотою 510 МГц та відповідним стандартним пакетом програмного забезпечення вказаної фірми для обстеження венозної системи. Пацієнтів обстежували у другій половині дня у вертикальному та горизонтальному положення. Під час ультразвукового дослідження оцінювали наявність кровотоку у венах, діаметри та форми просвіту вен, їх деформацію та мішкоподібну трансформацію, товщину стінок, однорідність, еластичність клапанів, їх функцію під час навантажувальних гідростатичних проб, наявність рефлюксу крові, тривалість ретроградного потоку по венозних магістралях, а також його поширення на анатомічні сегменти, стан сафено-феморального та сафено-поплітеального співусть. Після операції (тиждень, 1, 3, 6, 12 місяців, 2 роки) виконували клініко-сонографічне дослідження для виявлення ускладнень ЕВЛК, в тому числі рецидиву ВХ та реканалізації ВПВ.

ЕВЛК здійснювалася вітчизняним портативним високоінтенсивним напівпровідниковим (діодним) лазерним апаратом "Ліка-хірург" виробництва Черкаського МПП “Фотоніка Плюс" із довжиною хвилі 940 нм, потужністю 17,5-20 Вт у безперервному режимі. Втручання здійснювали під загальним знеболюванням або спинномозковою анестезією за протоколом, поданим Л. М. Чернухою та співавт.

Результати досліджень та їх обговорення. Нами проведено порівняльний аналіз рецидивів варикозної хвороби у 54 хворих (перша група), у яких ЕВЛК виконували без кросектомії, із 199 пацієнтами, у яких ЕВЛК поєднували із кросектомією та перев'язкою пригирлових приток (друга група).
Встановлено, що в першій групі рецидив ВХ за рахунок рефлюксу в сафено-феморальному гирлі (довга кукса та активно функціонуючі пригирлові притоки) виник у 17 (31,5 \%) хворих. У двох хворих $(3,7 \%)$ виник гострий тромбоз загальної стегнової вени внаслідок розповсюдження тромбу, що виник у сафено-феморальному гирлі. Водночас в другій групі хворих відсоток рецидиву ВХ значно менший - 24 (12,0 \%) пацієнти. Явищ прогресування тромботичного процесу в глибоку венозну систему не виявлено. Більше того, в першій групі хворих за допомогою УЗД встановлено, що міхурці газу, які утворювались внаслідок вапоризації, утримуються в просвіті вени до 20-30 хв і мають тенденцію до міграції через стегнову вену в центральну венозну систему. Цим ефектом можна пояснити виникнення в післяопераційному періоді головного болю, головокружіння, нудоти, “важкості” при диханні, загальної слабості та нездужання. Дані симптоми утримувалися близько 7 днів. Таким чином, ми $\epsilon$ прихильниками виконання ЕВЛК, що доповнюється кросектомією із перев' язкою пригирлових приток. Критеріями для відбору хворих для ЕВЛК без кросектомії, на нашу думку, повинні бути чітко узгоджені показання, що включають: діаметр ВПВ, відсутність остіального рефлюксу, здатного привести до “розмивання" оклюзуючого тромбу, відсутність крупних пригирлових приток із патологічним рефлюксом, відсутність розширеного сафено-феморального гирла або його аневризми.

Ми також провели аналіз реканалізації ВПВ та МПВ після ЕВЛК. На нашу думку, це принципове питання на користь використання того чи іншого виду лазерів (Н - гемоглобінових або W - водних). Аналіз показав, що дотримання вищевказаних технічних параметрів лазерного випромінювання та безперервна тракція світловода зі швидкістю 510 мм за секунду дає (через 12 місяців спостереження) дуже низький відсоток реканалізації вени 4,3 \% (11 пацієнтів). Це додатково підтверджує ефективність $\mathrm{H}$ - гемоглобінових лазерів.

Окремо стоїть питання про діаметр ВПВ, при якому можливе виконання ЕВЛК. Чіткої відповіді в науковій літературі не знайдено. Одні науковці стверджують про допустимі параметри діаметра вени до 10 мм, інші вважають, що можна проводити ЕВЛК при діаметрі вени більше 10 мм. Щоб відповісти на це запитання, ми, за допомогою ультразвукового дослідження, у 65 хворих на ВХНК провели визначення діаметра ВПВ на різних рівнях нижньої кінцівки, у положенні “стоячи” та “лежачи”. Встановлено, що у положенні “стоячи” та “лежачи" діаметр ВПВ на рівні сафено-феморального гирла був, відповідно, $(10,3 \pm 0,9)$ та $(7,45 \pm 0,6)$ мм; 
верхня третина стегна - $(7,4 \pm 0,8)$ та $(5,9 \pm 0,6)$ мм; середня третина стегна - $(6,8 \pm 0,7)$ та $(5,5 \pm 0,5)$ мм; нижня третина стегна - $(6,6 \pm 0,5)$ та $(5,4 \pm 0,6)$ мм; верхня третина гомілки $-(5,1 \pm 0,4)$ та $(4,3 \pm 0,5)$ мм $(\mathrm{p}<0,05)$. Таким чином, якщо брати до уваги діаметр ВПВ у верхній третині стегна (більше 10 мм) у вертикальному положенні, то майже в усіх хворих необхідно утриматись від виконання ЕВЛК (71 \% наших спостережень). Разом з тим, виконання УЗД у положенні пацієнта "лежачи" дає значне зменшення діаметра ВПВ на всіх рівнях стегна, що вкладається у параметри, необхідні для виконання ЕВЛК, яка власне і здійснюється в цьому положенні.

На нашу думку, обов'язкове виконання паравазальної тумесцентної інфільтрації розчином Клейна дозволяє додатково посилити коагуляційний ЕВЛК на стінку вени. Так, згідно з нашими ультра-

\section{СПИСОК ЛІТЕРАТУРИ}

1. Беленцов С. М. Может ли диаметр большой подкожной вены служить критерием отбора больных для проведения склеро- или термооблитерации? / С. М. Беленцов, И. А. Золотухин, Е. Е. Кунцева // Флебология. - 2009. - № 4. - С. 3-6.

2. Гощинський В. Б. Лікувально-діагностичний алгоритм у хворих на хронічну венозну недостатність в умовах варикозної хвороби / В. Б. Гощинський, О.Б.Луговий, І. Я. Зима // Архив клинической и експериментальной медицины. - 2010. T. 19, № 1. - С. 48-51.

3. Гощинський В. Б. Структура післяопераційних ускладнень після виконання ендовенозної лазерної коагуляції варикозних вен нижніх кінцівок / В. Б. Гощинський, М. В. Гаврилюк, П. В. Гощинський // Вісник наукових досліджень. - 2012. № 2. - С. 121-122.

4. Покровский А. В. Эндовазальная лазерная коагуляция в лечении варикозной болезни / А. В. Покровский, С. В. Сапелкин, Е. А. Летуновский // Материалы VI конференции Ассоциации флебологов России. - М., 2006. - С. 146.

5. Шайдов Е. В. Сравнение лазеров длиной волны 970 и 1470 нм при моделировании эндовазальной лазерной облитерации вен in vitro / Е. В. Шайдов, Е. А. Илюхин, А. В. Петухов // Флебология. -2011 . - № 4. - С. 23-29.

6. Ширяев Е. А. Эндовенозная лазерная коагуляция (ЭВЛК) и комбинированное хирургическое лечение варикозной болезни / Е. А. Ширяев, А. В. Брюнин, В. Ю. Богачев // Материалы VI конференции Ассоциации флебологов России. - М., 2006. C. 132.

7. Disselhoff B. C. Endovenous laser ablation: an experimental звуковими дослідженнями, проведеними у 35 хворих, при створенні тумесцентної паравазальної інфільтрації діаметр просвіту ВПВ зменшується до $(3,1 \pm 0,4)$ мм $(\mathrm{p}<0,05)$ і таким чином стає близьким до діаметра світловоду.

Висновок. Необхідно переглянути деякі технічні й тактичні умови для виконання ендовенозної лазерної коагуляції вен із метою збільшення іiі ефективності.

Перспективи подальших досліджень. Слід продовжити наукові дослідження щодо щільності лазерного випромінювання, необхідного для здійснення повної оклюзії вени певного діаметра та встановлення причин виникнення ускладнень після виконання ЕВЛК.

study on the mechanism of action / B. C. Disselhoff// Phlebology. 2008. - Vol. 23 (2). - P. 69-76.

8. Chang C. J. Endovenous laser photocoagulation (EVLP) varicose veins / C. J. Chang, J. J. Chua // Lasers Surg. Med. - 2002. Vol. 31. - P. 257-262.

9. Kabnic L. S. Outcome of different endovenous laser wavelengthts for great saphenous vein ablation / L. S. Kabnic // J. Vasc. Surg. - 2006. - Vol. 43(1). - P. 88-93.

10. Min R. J. Endovenous laser Treatment of saphenous vein reflux: long-term results / R. J. Min, N. Khilnani, S. E. Zimmer // J. Vasc. Interv. Radiol. - 2003. - Vol. 14. - P. 991-996.

11. Mundy 1. Systematic review of endovenous laser treatment for varicose vein / I. Mundy, T. L. Merlin, R. A. Fitridge // Br. J. Surg. - 2005. - Vol. 92. - P. 1189-1194.

12. Oh C. K. Endovenous laser surgery of the incompetent greater saphenous vein with $980 \mathrm{~nm}$ diode lazer / C. K. Oh, D. S. Jung, H. S. Jung // Dermatol. Surg. - 2003. - Vol. 29. - P. 1135-1140. 13. Neovascularisation and recurrence 2 years after varicose vein treatment for sapheno-femoral and great saphenous vein reflux: a comparison of surgery and endovenous laser ablation / N. S. Theivacumar, R. Darwood, M. J. Gough // Eur. J. Vasc. Endovasc. Surg. - 2009. - Vol. 38 (2). - P. 203-207.

14. Van den Bos R. Endovenous therapies of lower extremity varicosities: a meta-analysis / R. Van den Bos, L. Arends, M. Kockaert // J. Vasc. Surg. - 2009. - Vol. 49 (1). - P. 230-239. 15. Vuylsteke M. Endovenous laser treatment: a morphological study in an animal model / M. Vuylsteke // Phlebology. - 2009. Vol. 24(4). - P. 166-175. 